\title{
Food-limited invertebrate larvae in the Southern Ocean: testing a paradigm
}

\author{
J. Ameneiro ${ }^{1, *}$, L. M. Lubián ${ }^{2}$, P. Sangrà ${ }^{3}$, E. Vázquez ${ }^{1}$ \\ ${ }^{1}$ Dpt. Ecoloxía e Bioloxía Animal, Facultade de Ciencias do Mar, Universidade de Vigo, 36200 Vigo, Spain \\ ${ }^{2}$ Instituto de Ciencias Marinas de Andalucía (CSIC), Av. República Saharaui 2, 11510 Puerto Real, Spain \\ ${ }^{3}$ Dpt. Física, Facultad de Ciencias del Mar, Universidad de Las Palmas de Gran Canaria, 35017 Las Palmas de Gran Canaria, Spain
}

\begin{abstract}
A long-standing paradigm of larval ecology is that the high incidence of non-feeding larval development in Antarctic invertebrates is an adaptation to limited availability of algal food. Antarctic plankton communities have a relatively high diversity and abundance of invertebrate larvae, some of which are planktotrophic and synchronize the presence of feeding larval stages to peaks in summer phytoplankton. Among the echinoderm larvae found between 30 December 2002 and 7 January 2003 in the Bransfield Strait, the planktotrophic brachiolaria of Odontaster were the most abundant. Although phytoplankton is the main food source for planktotrophic larvae of asteroids in other oceans, previous estimates of the carbon requirements of larvae of the Antarctic asteroid $O$. validus have indicated that these larvae could not survive on natural levels of Antarctic phytoplankton. The main aims of the present study were to establish whether the abundance of Odontaster larvae is related to that of palatable phytoplankton and to determine whether the availability of the latter would be sufficient to cover the carbon requirements of the larvae. We found that of all palatable phytoplanktonic groups (Cryptophyceae, picoplankton, nanoplankton and ultraplankton), only Cryptophyceae was a significant predictor of brachiolaria abundance, along with the stratification index. We also found that the carbon content of the total palatable phytoplankton would be sufficient to meet the carbon requirements of Odontaster larvae at almost all stations and depths. Although $O$. validus spawns between mid- and late winter when the concentration of phytoplankton is lowest, winter spawning may be one way of meeting the exogenous energetic requirements of larvae.
\end{abstract}

KEY WORDS: Meroplankton · Phytoplankton - Antarctica · Brachiolaria - Cryptophyceae · Larval starvation · Odontaster

Resale or republication not permitted without written consent of the publisher

\section{INTRODUCTION}

Recent studies of Antarctic meroplankton have revealed a relatively high diversity and abundance of larval forms of benthic marine invertebrates (reviewed by Arntz \& Gili 2001, Sewell 2005, Vázquez et al. 2007, Bowden et al. 2009, Ameneiro et al. 2012), only some of which are planktotrophic. The paucity of planktotrophic larvae in polar habitats has traditionally been explained by a lack of algae as food (reviewed by Gillespie \& McClintock 2007, Pearse et al. 2009). However, research carried out in the Antarctic Ocean and South America has shown no correlation between latitude (in relation to temperature and seasonality) and larval type (Stanwell-Smith et al. 1999, Pearse \& Lockhart 2004) and, in fact, some evidence indicates that this may be a consequence of isolation after vicariant events that have led to proliferation of species with non-pelagic development (Poulin et al. 2002, reviewed by Pearse et al. 2009). Nevertheless, some of the most abundant species in these cold-water habitats have planktotrophic larvae 
(Pearse \& Lockhart 2004). These species reproduce seasonally, usually in late winter and early spring, synchronizing their planktotrophic larvae with the summer phytoplankton bloom (Pearse et al. 1991, Pearse \& Bosch 2002, Pearse \& Lockhart 2004, Bowden et al. 2009). This has already been shown for echinoderm larvae and nemertean pilidia, which occur in the water column when the flagellate chlorophyll fraction $(2-20 \mu \mathrm{m})$ exceeds the diatom chlorophyll fraction (Stanwell-Smith et al. 1999), which may be unpalatable (Perissinotto 1992).

In the Bransfield Strait, the meroplankton community is dominated by polychaete and echinoderm larvae (Vázquez et al. 2007), and its distribution depends on water masses, depth and fronts. Thus, polychaete larvae were mainly found close to the South Shetland Islands Slope in Transitional Zonal Water with Bellingshausen influence, below $100 \mathrm{~m}$ depth in the central basin in Transitional Zonal Water with Weddell influence, and in upper layers at stations between the Peninsular Front and the Antarctic Peninsula, in Transitional Zonal Water with Weddell influence (Vázquez et al. 2007). By contrast, echinoderm larvae mainly occupied the central basin and were always associated with the upper $100 \mathrm{~m}$ in the well-stratified Transitional Zonal Water with Bellingshausen influence, just above the polychaete larvae (Vázquez et al. 2007).

Approximately $98 \%(n=3200)$ of the echinoderm larvae were the planktotrophic brachiolaria of Odontaster (Vázquez et al. 2007). Five species of Odontaster have been described in the Southern Ocean and southern South America (reviewed by Pearse 2013). O. meridionalis (Smith) and O. validus Koehler display a circum-Antarctic distribution (McClintock et al. 1988), whereas O. penicillatus (Philippi, 1879) shows an almost entirely sub-Antarctic distribution off Argentina, co-occurring with the other 2 species, mainly off South Georgia Island in the Southern Ocean. O. pearsei Janosik \& Halanych, 2010, inhabits the western side of the Antarctic Peninsula, and O. roseus Janosik \& Halanych, 2010, inhabits the South Shetland Islands off the northern tip of the Antarctic Peninsula (Pearse 2013). O. validus usually occurs at much higher densities (Dayton et al. 1974) and is the most abundant and ubiquitous shallowwater asteroid around the Antarctic continent, especially between 0 and $200 \mathrm{~m}$ depth (Pearse 1965, McClintock et al. 1988, Dayton 1990, Chiantore et al. 2002). O. validus, O. meridionalis and O. roseus have long-lived planktotrophic larvae (Bosch \& Pearse 1990, Stanwell-Smith \& Peck 1998, Janosik et al. 2011) as do the other 2 species (Pearse 2013). O. validus spawns synchronously and seasonally between mid- and late winter (Pearse 1965, StanwellSmith \& Clarke 1998, Stanwell-Smith \& Peck 1998) when the concentration of phytoplankton is very low (Rivkin 1991). However, the free-swimming feeding forms of larvae remain in the plankton for more than 5.5 mo (Pearse \& Bosch 1986, Stanwell-Smith \& Peck 1998 ) during the entire period of summer phytoplankton production (Pearse \& Bosch 2002).

The availability of food for planktotrophic larvae remains unclear. Phytoplankton is the main source of food for planktotrophic larvae of asteroids in other oceans. However, estimation (from respiration data) of the carbon requirements of larvae of the Antarctic asteroid $O$. validus suggested that these larvae could not survive by feeding only on Antarctic phytoplankton, although larvae held in situ in mesh cages did survive (Olson et al. 1987). Consequently, it has been suggested that the larvae can use other sources of nutrition, such as bacteria (Rivkin et al. 1986, Rivkin 1991, but see Pearse et al. 1991), detritus (Strathmann 1971, Rassoulzadegan \& Fenaux 1979, Bosch \& Rivkin 1988) and directly absorbed dissolved organic matter (DOM) (Manahan et al. 1983, Shilling \& Manahan 1991).

The aims of this study were to explore the relationship between the abundance of Odontaster larvae and the phytoplankton smaller than $20 \mu \mathrm{m}$, which can be ingested by Odontaster larvae, and to study whether the abundance of phytoplankton would be sufficient to cover the carbon requirements of Odontaster larvae in the Bransfield Strait, Antarctica.

\section{MATERIALS AND METHODS}

Plankton sampling was carried out from the RV B.I.O. 'Hespérides' along 4 transects of 60 nautical miles (nmi), each separated by $20 \mathrm{nmi}$, in the Bransfield Strait (Fig. 1) running from the Antarctic Peninsula to the South Shetland Islands, between 30 December 2002 and 7 January 2003.

Phytoplankton samples were collected every $20 \mathrm{nmi}$ along transect $\mathrm{T} 1$ and every $10 \mathrm{nmi}$ along transects T2, T3 and T4 (Fig. 1), with a Neil Brown Mark III conductivity, temperature, depth (CTD)/Rossette Niskin sampler, at the following depths: 5, 10, 25, 50 and $100 \mathrm{~m}$ and at the deep chlorophyll maximum. Samples were fixed in 3\% formaldehyde and analysed immediately by flow cytometry (FACSCalibur, Becton Dickinson). Acquisition and data analysis were carried out with CELLQuestTM software (Becton Dickinson). Picoplankton $(<2 \mu \mathrm{m})$, ultraplankton 

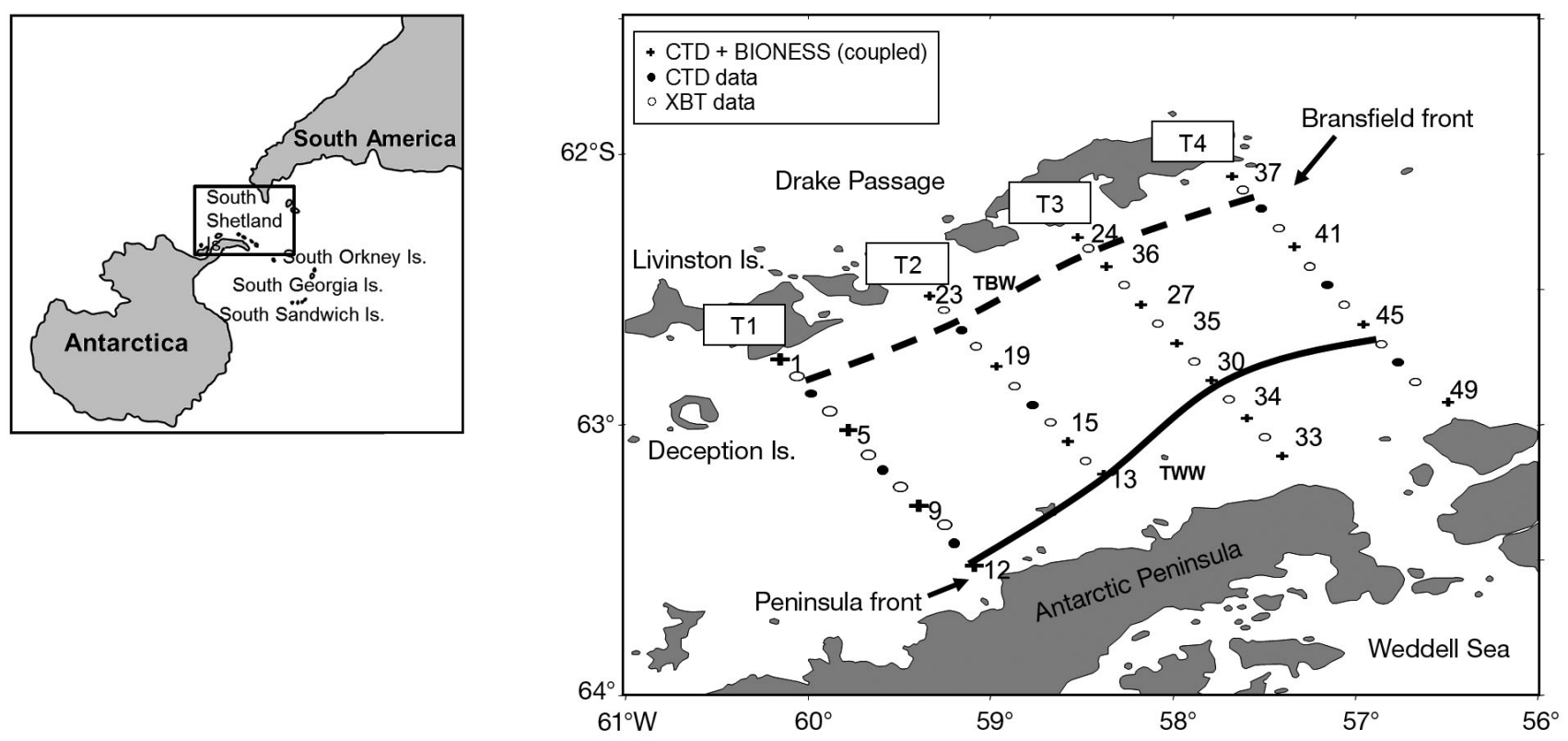

Fig. 1. Location of the sampling stations in the Central Basin of the Bransfield Strait (Antarctica), showing conductivity, temperature and depth (CTD) and expendable bathythermograph (XBT) monitoring points, and the CTD+BIONESS ('coupled') stations (numbered). Dashed line: position of the Bransfield Front; solid line: position of the Peninsular Front that separates the Transitional Zonal Water with Bellingshausen influence (TBW) and the Transitional Zonal Water with Weddell influence (TWW). T1-T4: transects 1-4

$(2-8 \mu \mathrm{m})$, nanoplankton $(8-20 \mu \mathrm{m})$ and Cryptophyceae were separated by using combinations of 2dimensional gates based on orange fluorescence, red fluorescence and side scatter (SSC) signal. The SSC signal was converted to biovolume $\left(\mathrm{BV}\right.$, in $\left.\mu^{3}{ }^{3}\right)$ by applying the empirical relationship shown in Eq. (1) below. The regression equation was obtained by measuring the BV of 4 different cultures of phytoplankton (measured by optic imagery) and comparing the results with the SSC signal. The BV was converted to carbon by applying Eq. (2), proposed by Verity et al. (1992):

$$
\begin{aligned}
& \mathrm{BV}\left(\mu \mathrm{m}^{3}\right)=0.3534 \times \mathrm{SSC}+2.885 \\
& \left(\mathrm{r}^{2}=0.928 ; \mathrm{n}=4 ; \mathrm{p}<0.01\right) \\
& \text { pg } \mathrm{C}=0.433 \times \mathrm{BV}^{0.863} \\
& \left(r^{2}=0.984\right)
\end{aligned}
$$

The data were subsequently depth integrated (surface to $100 \mathrm{~m}$ ) according to the following equation:

$$
B_{S}=\sum_{0}^{100}\left(D_{i}+D_{i+1}\right) / 2\left(Z_{i}+Z_{i+1}\right)
$$

where $B_{S}$ is the phytoplankton biomass $\left(\mathrm{mg} \mathrm{C} \mathrm{m}^{-2}\right)$ at Stn $S, D_{i}$ and $D_{i+1}$ is the amount of carbon measured (mg) at depth $i$ and $i+1$, and $Z_{i}$ and $Z_{i+1}$ is the depth at which samples are taken (m).

Zooplankton was sampled at 4 stations (separated by $20 \mathrm{nmi}$ ) on transects T1, T2 and T4 and at 7 stations (separated by $10 \mathrm{~nm}$ ) on transect T3, with a multinet (BIONESS, Open Seas Instrumentation). These stations are designated 'coupled stations' in Fig. 1. The multinet comprises a quadrangular $1 \mathrm{~m}^{2}$ frame with 5 double nets. The mesh size of the inner net and its cod-end is $250 \mu \mathrm{m}$, and the mesh size of the outer net and its cod-end is $80 \mu \mathrm{m}$. The standard procedure used was to lower the net to a depth of $300 \mathrm{~m}$ (or close to the bottom if the depth was less than $300 \mathrm{~m}$ ), and to carry out an oblique ascending tow, opening the nets at the desired ranges of depth: 300-200, 199-100, 99-70, 69-40 and 39-10 m. Sampling was not carried out between the surface and $10 \mathrm{~m}$, because the turbulence created by the vessel at this depth could have damaged the delicate nets. The towing speed was approximately 2 knots. The mean tow duration was $5 \mathrm{~min} 48 \mathrm{~s} \pm 1 \mathrm{~min} 34 \mathrm{~s}(\mathrm{SE})$, and approximately $250 \mathrm{~m}^{3}$ of seawater were filtered per depth interval (mean swept water volume $=252.72 \pm$ $61.73[\mathrm{SE}] \mathrm{m}^{3}$ ). The larval counts for each tow were therefore corrected to a standard sampling volume of $200 \mathrm{~m}^{3}$. To analyse the horizontal distribution, the number of larvae $\mathrm{m}^{-2}$ integrated over the entire depth was calculated as follows:

$$
N_{s}=\sum_{i}\left(b_{i} \times Z_{i} / V_{i}\right)
$$

where $N_{s}$ is the number of larvae $\mathrm{m}^{-2}$ at $\operatorname{Stn} S, b_{i}$ is the number of larvae caught at depth interval $i, v_{i}$ is 
the volume filtered $\left(\mathrm{m}^{3}\right)$ for depth interval $i$, and $Z_{i}$ is the thickness of the depth interval $i(\mathrm{~m})$. Zooplankton was anaesthetised (with menthol crystals in sea water) for $4 \mathrm{~h}$ prior to being fixed and preserved in $4 \%$ formaldehyde in seawater solution. All samples ( $\mathrm{n}=176)$ were examined under a binocular microscope, and the larvae were counted.

Echinoderm larvae can feed on particles of a wide range of sizes; however, they generally retain 2-20 $\mu \mathrm{m}$ particles most efficiently (Boidron-Métairon 1995) and cannot ingest spheres larger than $65 \mu \mathrm{m}$ (Strathmann 1971). Therefore, only phytoplankton smaller than $20 \mu \mathrm{m}$ was considered suitable for larval ingestion and designated 'palatable phytoplankton' in the text. Diatoms such as Corethron criophilum and Proboscia sp. (diameter around $100 \mu \mathrm{m})$, Thalassiosira spp. (diameter $65 \mu \mathrm{m}$ and mainly appearing in long chains) and Fragilariopsis sp. (average diameter around $50 \mu \mathrm{m}$ ) were therefore not considered in this study.

Multiple linear regression analysis was used to examine the relationships between total number of brachiolaria larvae of Odontaster (expressed as larvae $\mathrm{m}^{-2}$ ) at each station (dependent variable) and the abundances of nanoplankton, picoplankton, ultraplankton and Cryptophyceae (integrated biomass for each station to a depth of $100 \mathrm{~m}$ expressed as mg C $\mathrm{m}^{-2}$ ) (independent predictors). All variables were previously transformed by applying the expression $\operatorname{Ln}(x+1)$. The potential density anomaly $(\sigma)$ was added to this set of explanatory variables as a stratification index, as the potential density profiles indicated a stratified water column in the central part of Bransfield Strait where Odontaster larvae were found (Vázquez et al. 2007). The index was calculated as the difference between potential density anomaly at $200 \mathrm{~m}$ (maximum larvae depth) and at $5 \mathrm{~m}$. The potential density $\left(\rho_{\theta}\right)$ of a fluid parcel at pressure $P$ is the density that the parcel would acquire if adiabatically brought to a reference pressure $P_{0}$ (often 1 bar, $100 \mathrm{kPa}) . \rho_{\theta}$ is especially useful because it is a conserved thermodynamic property. Although density varies with pressure, the potential density of a fluid parcel is conserved as the pressure experienced by the parcel varies. To avoid the difficulties associated with determining absolute density, the density is expressed relative to that of pure water. For simplification, the final 2 digits of the density are often quoted, a quantity named density anomaly or $\sigma$. The corresponding potential density anomaly is denoted by

$$
\sigma_{\theta}=\rho_{\theta}-1000 \mathrm{~kg} \mathrm{~m}^{-3}
$$

The carbon requirements of Odontaster larvae were estimated from all published values of oxygen consumption (pmol O $\mathrm{h}^{-1}$ larva $^{-1}$; Table 1) by using the following equation (Parsons et al. 1984):

$$
C=R \times 0.536 \times \mathrm{RQ}
$$

where $C$ is the carbon requirement ( $\mu \mathrm{g} C), R$ is the respiration rate $\left(\mu l \mathrm{O}_{2} \mathrm{~h}^{-1}\right)$ and $\mathrm{RQ}$ is the respiratory quotient. The RQ of organisms feeding on phytoplankton is usually about 1.

The filtration rates required for an Odontaster larva to meet the carbon requirements shown in Table 1 were estimated for each sampling depth and station in the Bransfield Strait, in relation to all palatable phytoplankton, taking into consideration that the highest filtration rate reported for an Odontaster larva at $-1^{\circ} \mathrm{C}$ is $0.593 \mathrm{ml} \mathrm{h}^{-1}$ (Rivkin et al. 1986).

\section{RESULTS}

The size-fractionated measurements of phytoplankton carbon $\left(\mathrm{mg} \mathrm{C} \mathrm{m}^{-2}\right)$ suitable for ingestion by brachiolaria larvae and the total abundance of brachiolaria larvae are shown in Fig. 2. In the Bransfield Strait, the Peninsular Front defined the distribution limit of most species of phytoplankton. The Cryptophyceae population was concentrated in the central part of the Bransfield Strait, north of the Peninsular Front, and its distribution appeared to be associated with the transitional waters with Bellingshausen influence (TBW) (Fig. 2B) and with the presence of brachiolaria larvae (Fig. 2A). The distribution of the remaining small groups of phytoplankton was associated with the transitional waters with Weddell Sea

Table 1. Carbon requirements $\left(\mathrm{C}_{i}\right.$ ng $\left.\mathrm{C} \mathrm{h}^{-1} \mathrm{larva}^{-1}\right)$ based on oxygen consumption values reported in the literature. The $V$ $\left(\mathrm{nl} \mathrm{O}_{2}\right)$ values were calculated using the Ideal Gas Law $(P V=$ $n R T$, where $n$ is moles (mol), $R=0.082 \mathrm{latm} \mathrm{mol}^{-1} \mathrm{~K}^{-1}, T$ is

\begin{tabular}{|c|c|c|c|c|}
\hline $\begin{array}{r}\text { Con } \\
\mathrm{p}_{\mathrm{p}}^{-1}\end{array}$ & $\begin{array}{l}\mathrm{O}_{2} \\
\text { sumption } \\
\text { mol O}_{2} \\
\text { larva }^{-1} \text { ) }\end{array}$ & $\begin{array}{c}V \\
(\mathrm{nl})\end{array}$ & ${ }^{\circ} \mathrm{C}$ & $\begin{array}{c}\mathrm{C}= \\
R \times \\
0.536\end{array}$ \\
\hline Marsh \& Manahan (1999) & 13 & 0.29 & -1.5 & 0.16 \\
\hline Shilling \& Manahan (1994) & 2.22 & 0.05 & -2 & 0.03 \\
\hline Olson et al. (1987) & & 1.70 & -1.8 & 0.91 \\
\hline \multicolumn{5}{|c|}{ Peck \& Prothero-Thomas (2002): } \\
\hline Mean in 1993 & 23.8 & 0.53 & -0.5 & 0.29 \\
\hline Mean in 1997 & 35.7 & 0.80 & -0.5 & 0.43 \\
\hline Min. at $-0.5^{\circ} \mathrm{C}$ & 7.5 & 0.17 & -0.5 & 0.09 \\
\hline Max. at $-0.5^{\circ} \mathrm{C}$ & 77.68 & 1.74 & -0.5 & 0.93 \\
\hline Min. at $2^{\circ} \mathrm{C}$ & 18.3 & 0.41 & 2 & 0.22 \\
\hline Max. at $2^{\circ} \mathrm{C}$ & 54.7 & 1.23 & 2 & 0.66 \\
\hline
\end{tabular}
temperature in $\mathrm{K}, P$ is pressure in atm and $V$ is volume) 



influence (TWW) (Fig. 2C-E). The microplankton constituted a small fraction of phytoplankton biomass, with Corethron criophilum, Thalassosira spp. and Proboscia sp. being the most representative species, with maximum contributions to the total biomass of 9, 7 and $4 \%$, respectively (Lubián et al. 2007). Most of the biomass corresponded to the population

Fig. 2. (A) Distribution of Odontaster larval abundance (larvae $\mathrm{m}^{-2}$ ) integrated to $200 \mathrm{~m}$ and (B-E) depth-integrated $(0-100 \mathrm{~m})$ phytoplankton groups below $20 \mu \mathrm{m}\left(\mathrm{mg} \mathrm{C} \mathrm{m}^{-2}\right)$ in the Bransfield Strait, Antarctica, during summer 2003

of Cryptophyceae (22-90\%), followed by ultraplankton $(7-47 \%)$, nanoplankton $(0.7-18 \%)$ and picoplankton $(0.4-15 \%)$.

Multiple regression analysis of the abundance of brachiolaria larvae of Odontaster and abundance of all palatable phytoplanktonic groups (Cryptophyceae, picoplankton, nanoplankton and ultraplankton) at each station, along with the stratification index, showed that only Cryptophyceae was a significant predictor of brachiolaria abundance, and together with the stratification index explained $58.0 \%$ $(p=0.001)$ of the variation in larval abundance in the water column:

$\Sigma$ brachiolaria larvae $=-116.72+172.55 \sigma+15.45 \log$ Cryptophyceae 

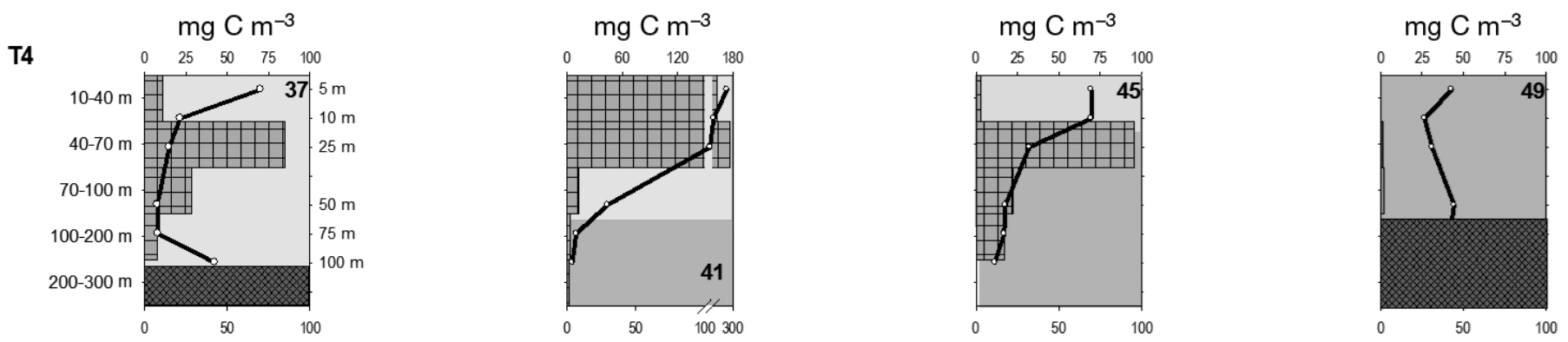

T3


$\mathrm{T} 2$
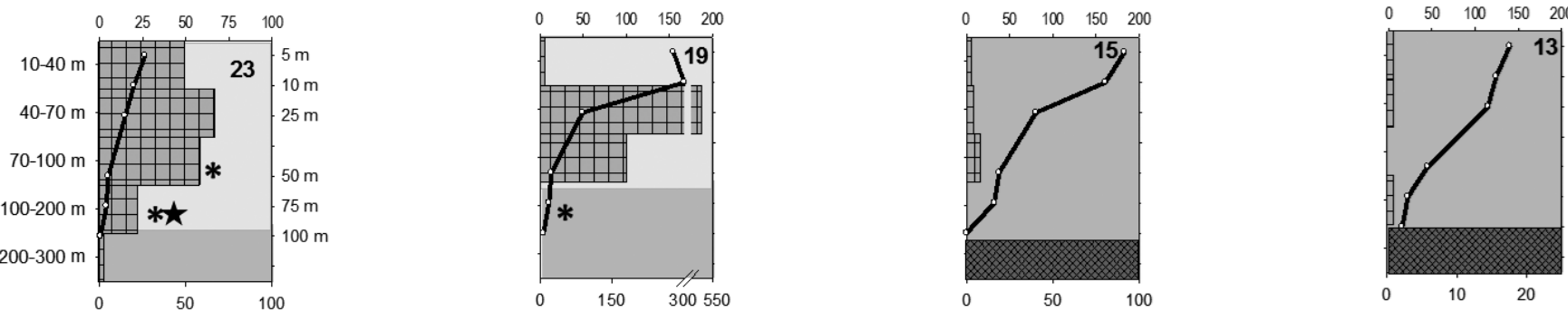

T1



0 50100150200250300



$0 \quad 25 \quad 5075 \quad 100125150$
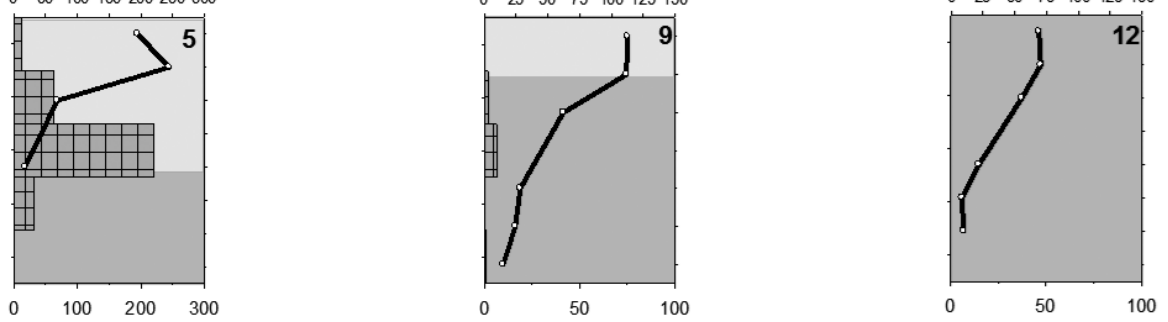

Odontaster larvae (no. $200 \mathrm{~m}^{-3}$ ) Odontaster larvae (no. $200 \mathrm{~m}^{-3}$ )

Odontaster larvae (no. $200 \mathrm{~m}^{-3}$ )

Fig. 3. Distribution of echinoderm larvae (cross-hatched bars) and all palatable phytoplankton (solid line) in the Bransfield Strait. Abundance is expressed as Odontaster larvae per $200 \mathrm{~m}^{3}$ (lower $x$-axis) and $\mathrm{mg} \mathrm{C} \mathrm{m}^{-3}$ (upper $x$-axis). The $y$-axes show depth (left: larvae, right: phytoplankton). The light (dark) grey area in each graph represents Transitional Zonal Water with Bellingshausen influence (Transitional Zonal Water with Weddell influence) and the very dark cross-hatched areas represent the sea floor at shallower stations. The order of the transects (T1-T4) and station numbering follow Fig. 1. Black asterisks indicate those stations/depths where the Cryptophyceae fraction alone would be insufficient to provide the carbon requirements of Odontaster larvae. The black star indicates the depth range where all palatable phytoplankton would not be sufficient to meet the carbon needs of Odontaster larvae (as these would have to filter more than $0.593 \mathrm{ml} \mathrm{h}^{-1}$ )

The highest abundance of brachiolaria larvae occurred in the central part of the Bransfield Strait, mainly in the shallowest layers between 40 and $70 \mathrm{~m}$ depth in the well-stratified TBW, except at Stn 45, where larvae were found in the TWW below $70 \mathrm{~m}$ (Fig. 3). Cryptophyceae with a spherical diameter of $6 \mu \mathrm{m}$ represented more than $75 \%$ of the total phytoplankton biomass at this station.

The estimated carbon requirements of Odontaster larvae were very variable, ranging from 0.03 to
$0.93 \mathrm{ng} \mathrm{C} \mathrm{h}^{-1}$ (Table 1), as they depend on the temperature at which the respiration measurements were made as well as on the highly variable oxygen consumption (high temperatures do not necessarily indicate higher oxygen consumption: $\mathrm{R}^{2}=0.02$; see Fig. S1 in the Supplement, available at www.int-res. com/articles/suppl/m554p071_supp.pdf). Nonetheless, even considering the highest carbon requirements, in the Bransfield Strait the intake of Cryptophyceae alone would ensure the carbon requirements of the 
Odontaster larvae at all stations and depths, except at 3 depths (Fig. 3). Furthermore, the total palatable fraction of phytoplankton would be sufficient, except at 1 station (Fig. 3), where an Odontaster larva would have to filter more than $0.593 \mathrm{ml} \mathrm{h}^{-1}$, its maximum filtration rate (Rivkin et al. 1986), to meet its carbon requirements from edible phytoplankton cells (see Table S1 in the Supplement).

\section{DISCUSSION}

Water mass distribution is of major importance in determining the spatial variability in the phytoplankton community in the Bransfield Strait. Examination of samples collected during the Bioantar-93 cruise (Mura et al. 1995) revealed that diatoms comprised a small fraction of phytoplankton biomass and were mainly distributed in the colder and saltier TWW (Lubián et al. 2007). Most of the biomass corresponded to Cryptophyceae located in TBW. Similarly, in the austral summer of 1993, the high phytoplankton biomass was clearly dominated by autotrophic nanoflagellates of the Cryptophyceae, represented by Cryptomonas indet. associated with a front in the Bransfield Strait (Mura et al. 1995). Kang \& Lee (1995) also reported a predominance of nanoflagellates such as Cryptomonas indet. and Phaeocystis antarctica (motile stage) in the Bransfield Strait, with these species accounting for $83 \%$ of the total phytoplankton carbon. Similarly, in the western region of the Antarctic Peninsula, the phytoplankton community was essentially formed by Cryptomonas indet. (Rodríguez et al. 2002, Varela et al. 2002). Greater stabilization of the water column with an initially poor diatom population was indicated as a possible explanation for the proliferation of nanoflagellates (Kopczynska 2008), although the grazing pressure by krill, which are very abundant in both the Peninsular and Bransfield fronts (Hernández-León et al. 2013), may determine the distribution of phytoplankton in this area (Varela et al. 2002).

In the present study, the other phytoplankton groups found made a modest contribution to the community biomass and were associated with the water mass from the Weddell Sea, although Mura et al. (1995) associated them with low-salinity waters from ice melt from the Bellingshausen Sea water mass.

Larval abundance and distribution of asteroid larvae have been poorly quantified. In regions of the Antarctic such as the Ross Sea, McMurdo Sound, Weddell Sea and Bransfield Strait, asteroid larvae are most abundant in winter and are dominated by Odontaster validus (Stanwell-Smith \& Clarke 1998, Stanwell-Smith \& Peck 1998, Bowden et al. 2009; reviewed by Metaxas 2013). In the Bransfield Strait, brachiolariae represent $23 \%$ (6 larvae $\mathrm{m}^{-3}$ ) of the meroplankton (Vázquez et al. 2007), in contrast to very low abundance of larvae in the Bellingshausen Sea (0-0.2 larvae $\mathrm{m}^{-3}$; Ameneiro et al. 2012). These spatial differences may reflect temporal variability, although (as for phytoplankton) the larval distribution in the Bransfield Strait is strongly dependent on water masses, depth and fronts (Vázquez et al. 2007).

The position of the larvae in the water column may be determined by their response to various abiotic (light, temperature, salinity, pressure, currents, turbulence) and biotic (predators, food) factors (Young 1995), thus varying their vertical position (Metaxas \& Young 1998, Metaxas \& Saunders 2009). Larvae of asteroids were mainly found in the upper layers in the Bransfield Strait (Vázquez et al. 2007) characterized by enhanced phytoplankton biomass. This is consistent with the findings of laboratory studies showing that asteroid larvae swim upwards and remain in the upper layers of the water column aggregating around or within areas with high phytoplankton concentrations (Metaxas \& Young 1998, Sameoto \& Metaxas 2008) to maximize their food intake and hence enhance their opportunities of larval survival and recruitment in the benthos (Metaxas \& Young 1998). The relative importance of different food sources is not known, although size-selective feeding occurs (reviewed by Metaxas 2013). Echinoderm larvae can feed on suspended particles of a wide range of sizes, although those of size 4 to $6 \mu \mathrm{m}$ are captured most efficiently. Echinoderm larvae also preferentially ingest certain species of algae, excluding particles that are too large or unsuitable as food (Strathmann 1971, Okaji et al. 1997). Unsurprisingly, the abundance of brachiolariae was related to the most abundant of the palatable phytoplankton (picoplankton, ultraplankton and nanoplankton), particularly nanoplanktonic Cryptophyceae (spherical diameter $6 \mu \mathrm{m})$, which are similar in size to other asteroid larvae (Strathmann 1971, Rassoulzadegan \& Fenaux 1979, Ayukai 1994, Basch 1996, Okaji et al. 1997). Moreover, use of this dominant component of phytoplankton is advantageous for the survival of planktotrophic larvae in the field (Rassoulzadegan \& Fenaux 1979).

Odontaster larvae must survive for long periods in an environment with low food supply for most of the year, as the concentration of chlorophyll a ( $\mathrm{chl} \mathrm{a}$ ) in Antarctic waters is typically up to 2 orders of magni- 
tude lower than the amount considered limiting (Rivkin et al. 1986). Indeed, Olson et al. (1987) concluded that the concentration of carbon in the form of phytoplankton in McMurdo Sound in September and October (1500 ng C $\mathrm{l}^{-1}$, based on chl a concentration) was insufficient to support the carbon requirements of bipinnaria larvae of $O$. validus. However, in situ experiments did not show any evidence of either larval starvation or food limitation (Olson et al. 1987). Additional nutritional resources such as dissolved organic compounds (Manahan et al. 1983) and bacteria (Rivkin et al. 1986, Bosch et al. 1990, Pearse et al. 1992) have been suggested to be important to O. validus survival, as Odontaster larvae develop equally well whether fed bacteria or a range of concentrations of algae (Bosch et al. 1990).

However, the carbon requirements of Odontaster larvae estimated from oxygen consumption values reported in the literature were very variable, ranging from 0.03 to $0.93 \mathrm{ng} \mathrm{C} \mathrm{h}{ }^{-1}$ (Table 1). This wide variation can be attributed to the different temperatures at which the respiration measurements were made and to the variability in oxygen consumption itself, as high temperatures do not necessarily indicate higher oxygen consumption (see Fig. S1 in the Supplement; $R^{2}=0.02$ ). Although a quantitative comparison of oxygen consumption is difficult due to differences in the methods used (Olson et al. 1987, Shilling \& Manahan 1994, Marsh \& Manahan 1999, Peck \& Prothero-Thomas 2002), even the most restrictive estimates indicate that in the Bransfield Strait in January, carbon from total palatable phytoplankton would be sufficient to meet the carbon requirements of Odontaster larvae at all stations and depths, except at 1 station. Furthermore, the Cryptophyceae fraction alone would provide enough food, except at 3 depths, at which an Odontaster larva would have to filter more than $0.6 \mathrm{ml} \mathrm{h}^{-1}$. The high clearance rate reported for Antarctic bipinnaria larva is similar to that reported for temperate echinoderm larvae (Lucas 1982, Hart 1991，1996, Ayukai 1994). This may reflect an adaptation for the rapid capture of small particles (Hart 1991), as Odontaster larvae have evolved features that partly compensate for the higher viscosity of Antarctic waters, such as characteristics of body shape and ciliary placement or dimensions (Pearse \& Pearse 1992, Hart 1996). Thus, surprisingly, the concentrations of both edible phytoplankton and Cryptophyceae would also be sufficient at most depths below $75 \mathrm{~m}$ (Table S1 in the Supplement).

The low polar temperatures imply slow metabolic rates and low energetic cost, which may be useful for species with long development times (Peck et al. 2006). The scarce metabolic studies of polar larvae, namely echinoderm larvae (Olson et al. 1987, Hoegh-Guldberg et al. 1991, Shilling \& Manahan 1994, Marsh \& Manahan 1999, Peck \& ProtheroThomas 2002, Peck et al. 2006, Malanga et al. 2007), have revealed much lower metabolic rates than in temperate larvae (Hoegh-Guldberg \& Manahan 1995, Peck et al. 2006). Egg biomass may therefore provide sufficient energy to meet metabolic demands during several months (Shilling \& Manahan 1994), until the summer phytoplankton blooms. Furthermore, the larvae could also meet their energy needs and gain biomass by absorbing and metabolizing some components of DOM (Shilling \& Bosch 1994). When these energy reserves are consumed, the larvae could cover exogenous carbon requirements by filtering nanophytoplankton, mainly Cryptophyceae, during the summer period of phytoplankton production (December to January), prior to settlement.

In Admiralty Bay, in Bransfield Strait, O. validus spawns when the concentration of phytoplankton is low (Freire et al. 2006), and the larvae are very abundant in December and January when phytoplankton biomass increases. The phytoplankton availability would thus enable the larvae to complete their development and would also meet the feeding requirements of the post-metamorphosis juvenile stages (Pearse 1965, Bowden et al. 2009). This may explain the presence of 27 larvae with a rudiment in our study, indicating that they were due to settle within a short period of time. Stanwell-Smith \& Clarke (1998) suggested that at Signy Island, O. validus spawns in winter to prevent predation by suspension feeders or to avoid the period when the water column is dominated by large diatoms, colonial forms and mucilage from microalgae. However, we suggest that in the Bransfield Strait, $O$. validus may spawn in winter so that the exogenous energetic requirements of larvae hatching in the summer will be covered by the relatively high concentration of palatable phytoplankton available at this time.

Acknowledgements. This study was part of the BREDDIES Project (REN2001-2650/ANT) and the COUPLING project (CTM2008-06343-C02/ANT) sponsored by the Spanish Ministry of Science and Technology. We thank Dr. J. Bellas, G. Macho and C. Martinez for field assistance, and all scientists participating in the BREDDIES survey for their support. We extend our thanks to the officers, crew and UTM technicians of RV 'Hespérides' for their invaluable help. We also thank Dr. J. Pearse and 2 anonymous reviewers whose valuable comments helped us to improve the manuscript. 


\section{LITERATURE CITED}

Ameneiro J, Mouriño-Carballido B, Parapar J, Vázquez E (2012) Abundance and distribution of invertebrate larvae in the Bellingshausen Sea (West Antarctica). Polar Biol 35:1359-1373

Arntz WE, Gili JM (2001) A case for tolerance in marine ecology: Let us not put out the baby with the bathwater. Sci Mar 65:283-299

> Ayukai T (1994) Ingestion of ultraplankton by planktonic larvae of the crown-of-thorns starfish, Acanthaster planci. Biol Bull (Woods Hole) 186:90-100

Basch LV (1996) Effects of algal and larval densities on development and survival of asteroid larvae. Mar Biol 126:693-701

Boidron-Métairon IF (1995) Larval nutrition. In: McEdward L (ed) Ecology of marine invertebrate larvae. CRC Press, Boca Raton, FL, p 223-248

Bosch I, Pearse JS (1990) Developmental types of shallowwater asteroids of McMurdo Sound, Antarctica. Mar Biol 104:41-46

Bosch I, Rivkin RB (1988) Feeding dynamics by planktotrophic asteroid larvae in oligotrophic environments. Am Zool 28:A167

Bosch I, Pearse JS, Basch LV (1990) Particulate food and growth of planktotrophic sea star larvae in McMurdo Sound, Antarctica. Antarct J US 25:201-212

> Bowden DA, Clarke A, Peck L (2009) Seasonal variation in the diversity and abundance of pelagic larvae of Antarctic marine invertebrates. Mar Biol 156:2033-2047

Chiantore M, Cattaneo-Vietti R, Elia L, Guidetti M, Antonini M (2002) Reproduction and condition of scallop Adamussium colbecki (Smith 1902), the sea-urchin Sterechinus neumayeri (Meissner 1900) and the sea-star Odontaster validus (Koehler 1911) at Terra Nova Bay (Ross Sea): different strategies related to inter-annual variations in food availability. Polar Biol 25:251-255

Dayton PK (1990) Polar benthos. In: Smith WO (ed) Polar oceanography, Part B: Chemistry, biology and geology. Academic Press, New York, NY, p 631-685

> Dayton PK, Robilliard GA, Paine RT, Dayton LB (1974) Biological accommodation in the benthic community at McMurdo Sound, Antarctica. Ecol Monogr 44:105-128

Freire AS, Absher TM, Cruz-Kaled AC, Kern Y, Elbers KL (2006) Seasonal variation of pelagic invertebrate larvae in the shallow Antarctic waters of Admiralty Bay (King George Island). Polar Biol 29:294-302

Gillespie JM, McClintock JB (2007) Brooding in echinoderms: How can modern experimental techniques add to our historical perspective? J Exp Mar Biol Ecol 342: 191-201

Hart MW (1991) Particle captures and the method of suspension feeding by echinoderm larvae. Biol Bull 180:12-27

Hart MW (1996) Variation in suspension feeding rates among larvae of some temperate, eastern Pacific echinoderms. Invertebr Biol 115:30-45

Hernández-León S, Sangrà P, Lehette P, Lubián L and others (2013) Zooplankton biomass and metabolism in the frontal zones of the Bransfield Strait, Antarctica. J Mar Syst 111-112:196-207

Hoegh-Guldberg O, Manahan DT (1995) Coulometric measurement of oxygen consumption during development of marine invertebrate embryos and larvae. J Exp Biol 198: 19-30

Hoegh-Guldberg O, Welborne JR, Manahan DT (1991)
Metabolic requirements of Antarctic and temperate asteroid larvae. Antarct J US 26:163-165

Janosik AM, Mahon AR, Halanych KM (2011) Evolutionary history of Southern Ocean Odontaster sea star species (Odontasteridae; Asteroidea). Polar Biol 34:576-586

Kang SH, Lee SH (1995) Antarctic phytoplankton assemblage in the western Bransfield Strait region, February 1993: composition, biomass, and mesoscale distributions. Mar Ecol Prog Ser 129:253-267

Kopczynska EE (2008) Phytoplankton variability in Admiralty Bay, King George Island, South Shetland Islands: six years of monitoring. Pol Polar Res 29:117-139

Lubián LM, Lama CM, Rodríguez-Gálvez S, García CM, Corzo A, Gordo C, Sangrá P (2007) Phytoplankton biomass in the Bransfield Strait (Antarctica): coupling with mesoscale structures. Symposium GLOBEC-IMBER Spain, Valencia

Lucas JS (1982) Quantitative studies of feeding and nutrition during larval stages of the coral reef asteroid Acanthaster planci (L.). J Exp Mar Biol Ecol 65:173-193

Malanga G, Estevez MS, Calvo J, Abele D, Puntarulo S (2007) The effect of seasonality on oxidative metabolism in Nacella (Patinigera) magellanica. Comp Biochem Physiol Part A Mol Integr Physiol 146:551-558

Manahan DT, Davis JP, Stephens GC (1983) Bacteria free sea urchin larvae: selective uptake of neutral amino acids from seawater. Science 220:204-206

Marsh AG, Manahan DT (1999) A method for accurate measurements of the respiration rates of marine invertebrate embryos and larvae. Mar Ecol Prog Ser 184:1-10

McClintock JB, Pearse JS, Bosch I (1988) Population structure and energetics of shallow-water Antarctic sea star Odontaster validus in contrasting habitats. Mar Biol 99: 235-246

Metaxas A (2013) Larval ecology, settlement and recruitment of asteroids. In: Lawrence JM (ed) Starfish: biology and ecology of the Asteroidea. Johns Hopkins University Press, Baltimore, MD, p 59-65

Metaxas A, Saunders M (2009) Quantifying the 'bio-'components in biophysical models of larval transport in marine benthic invertebrates: advances and pitfalls. Biol Bull (Woods Hole) 216:257-272

> Metaxas A, Young CM (1998) Responses of echinoid larvae to food patches of different algal densities. Mar Biol 130: 433-445

Mura MP, Satta MP, Agusti S (1995) Water-mass influence on summer Antarctic phytoplankton biomass and community structure. Polar Biol 15:15-20

Okaji K, Ayukai T, Lucas JS (1997) Selective feeding by larvae of the crown-of-thorns starfish, Acanthaster planci (L.). Coral Reefs 16:47-50

Olson RR, Bosch I, Pearse JS (1987) The hypothesis of Antarctic larval starvation examined for the asteroid Odontaster validus. Limnol Oceanogr 32:686-690

Parsons TR, Maita Y, Lalli CM (1984) A manual of chemical and biological methods for seawater analysis. Pergamon Press, Oxford

Pearse JS (1965) Reproductive periodicities in several contrasting populations of Odontaster validus Koehler, a common Antarctic asteroid. Biology of Antarctic Seas II. Antarct Res Ser 5:39-85

Pearse JS (2013) Odontaster validus. In: Lawrence JM (ed) Starfish: biology and ecology of the asteroidea. The Johns Hopkins University Press, Baltimore, MD, p 120-131 Pearse JS, Bosch I (1986) Are the feeding larvae of the com- 
monest Antarctic asteroid really demersal? Bull Mar Sci 39:477-484

> Pearse JS, Bosch I (2002) Photoperiodic regulation of gametogenesis in the Antarctic sea star Odontaster validus Koehler: evidence for a circannual rhythm modulated by light. Invertebr Reprod Dev 41:73-81

Pearse JS, Lockhart SJ (2004) Reproduction in cold water: paradigm changes in the 20th century and a role for cidaroid sea urchins. Deep-Sea Res II 51:1533-1549

Pearse JS, McClintock JB, Bosch I (1991) Reproduction of Antarctic benthic marine invertebrates: tempos, modes and timing. Am Zool 31:65-80

Pearse JS, Bosch I, Pearse VB, Basch LV (1992) Differences in feeding on algae and bacteria by temperate and Antarctic sea star larvae. Antarct J US 25:170-172

Pearse JS, Mooi R, Lockhart SJ, Brandt A (2009) Brooding and species diversity in the Southern Ocean: selection for brooders or speciation within brooding clades? In: Krupnik I, Lang MA, Miller SE (eds) Smithsonian at the Poles: contributions to International Polar Year Science. Proc Smithsonian at the Poles Symp, Smithsonian Institution Scholarly Press, Washington, DC, p 181-196

Pearse VB, Pearse JS (1992) Feeding rates of temperate and Antarctic sea-star larvae: a viscosity effect? Antarct J US 25:132-133

Peck LS, Prothero-Thomas E (2002) Temperature effects on the metabolism of larvae of the Antarctic starfish Odontaster validus, using a novel micro-respirometry method. Mar Biol 141:271-276

Peck LS, Clarke A, Chapman AL (2006) Metabolism and development of pelagic larvae of Antarctic gastropods with mixed reproductive strategies. Mar Ecol Prog Ser 318:213-220

Perissinotto R (1992) Mesozooplankton size-selectivity and grazing impact on the phytoplankton community of the Prince Edward Archipelago (Southern Ocean). Mar Ecol Prog Ser 79:243-258

Poulin E, Palma AT, Féral JP (2002) Evolutionary versus ecological success in Antarctic benthic invertebrates. Trends Ecol Evol 17:218-222

Rassoulzadegan F, Fenaux L (1979) Grazing of echinoderm larvae (Paracentrotus lividus and Arbacia lixula) on naturally occurring particulate matter. J Plankton Res 1: 215-223

Rivkin RB (1991) Seasonal patterns of planktonic production in McMurdo Sound, Antarctica. Am Zoo1 31:5-16

Rivkin RB, Bosch I, Pearse JS, Lessard EJ (1986) Bacterivory: a novel feeding mode for asteroid larvae. Science 233: 1311-1314

Rodríguez J, Jiménez-Gómez F, Blanco JM, Figueroa FL (2002) Physical gradients and spatial variability of the size structure and composition of phytoplankton in the

Editorial responsibility: James McClintock,

Birmingham, Alabama, USA
Gerlache Strait (Antarctica). Deep-Sea Res II 49:693-706

Sameoto JA, Metaxas A (2008) Interactive effects of haloclines and food patches on the vertical distribution of 3 species of temperate invertebrate larvae. J Exp Mar Biol Ecol 367:131-141

Sewell M (2005) Examination of the meroplankton community in the south-western Ross Sea, Antarctica, using a collapsible plankton net. Polar Biol 28:119-131

> Shilling FM, Bosch I (1994) 'Pre-feeding' embryos of Antarctic and temperate echinoderms use dissolved organic material for growth and metabolic needs. Mar Ecol Prog Ser 109:173-181

Shilling FM, Manahan DT (1991) Nutrient transport capacities and metabolic rates scale differently between larvae of an Antarctic and a temperate echinoderm. Antarct J US 26:158-160

Shilling FM, Manahan DT (1994) Energy metabolism and amino acid transport during early development of Antarctic and temperate echinoderms. Biol Bull (Woods Hole) 187:398-407

Stanwell-Smith D, Clarke A (1998) Seasonality of reproduction in the cushion star Odontaster validus at Signy Island, Antarctica. Mar Biol 131:479-487

Stanwell-Smith D, Peck L (1998) Temperature and embryonic development in relation to spawning and field occurrence of larvae of three Antarctic echinoderms. Biol Bull (Woods Hole) 194:44-52

> Stanwell-Smith D, Peck LS, Clarke A, Murray AWA, Todd CD (1999) The distribution, abundance and seasonality of pelagic marine invertebrate larvae in the maritime Antarctic. Philos Trans R Soc Lond B Biol Sci 354: 471-484

> Strathmann RR (1971) The feeding behaviour of planktotrophic echinoderm larvae: mechanisms, regulation, and rates of suspension-feeding. J Exp Mar Biol Ecol 6: $109-160$

> Varela M, Fernández E, Serret P (2002) Size-fractionated phytoplankton biomass and primary production in Gerlache and south Bransfield Strait (Antarctica Peninsula) in Austral summer 1995-96. Deep-Sea Res II 49:749-768

Vázquez E, Ameneiro J, Putzeys S, Gordo C, Sangrà P (2007) Distribution of meroplankton communities in the Bransfield Strait, Antarctica. Mar Ecol Prog Ser 338: $119-129$

> Verity PG, Robertson CY, Tronzo CR, Andrews MG, Nelson JR, Sieracki ME (1992) Relationship between cell volume and the carbon and nitrogen content of marine photosynthetic nanoplankton. Limnol Oceanogr 37:1434-1446

Young CM (1995) Behavior and locomotion during the dispersal phase of larval life. In: McEdward LR (ed) Ecology of marine invertebrate larvae. CRC Press, Boca Raton, FL, p 249-277

Submitted: March 5, 2015; Accepted: May 26, 2016 Proofs received from author(s): July 14, 2016 